\title{
ANALISIS DAN EVALUASI PENGALAMAN PENGGUNA PaTik BALI DENGAN METODE USER EXPERIENCE QUESTIONNAIRE (UEQ)
}

\author{
I Nyoman Saputra Wahyu Wijaya ${ }^{1}$, Putu Praba Santika ${ }^{2}$, Ida Bagus Ary Indra Iswara*3, I Nyoman Alit \\ Arsana $^{4}$ \\ ${ }^{1}$ Universitas Pendidikan Ganesha, ${ }^{2,3,4}$ STMIK STIKOM Indonesia \\ Email: ${ }^{1}$ wahyu.wijaya@undiksha.ac.id, ${ }^{2}$ praba@stiki-indonesia.ac.id, ${ }^{3}$ indraiswara@stiki-indonesia.ac.id, \\ ${ }^{4}$ alitarsana@stiki-indonesia.ac.id \\ *Penulis Korespondensi
}

(Naskah masuk: 23 November 2019, diterima untuk diterbitkan: 18 Maret 2021)

\begin{abstract}
Abstrak
PaTik Bali merupakan aplikasi keyboard virtual berbasis mobile. Keyboard PaTik berfungsi menulis aksara Bali. PaTik memiliki fitur autocorrection sesuai dengan pasang pageh aksara bali. Pada google playstore, jumlah perangkat terinstall lebih dari 89.000 perangkat mobile. Dalam penelitian ini ingin diketahui tingkat kenyamanan pengguna dari segi User Experience. Maka dalam penelitian ini dilakukan evaluasi pengalaman pengguna PaTik Bali. Evaluasi dilakukan dengan metode User Experience Questionnaire (UEQ). Kelengkapan aspek, yaitu attractiveness, pragmatic quality dan hedonic quality menjadi keunggulan User Experience Questionnaire (UEQ). Selain itu, sudah disedikan Data Analysist Tool dalam format excel untuk memudahkan pengukuran User Experience Questionnaire (UEQ). Evaluasi dilakukan pada suatu populasi yang berjumlah 34 data. Evaluasi User Experience Questionnaire (UEQ) memiliki penilaian yang baik. Daya tarik memiliki nilai ratarata 1.8, kejelasan memiliki nilai 1.7, Efisiensi memiliki nilai 1.6, Ketepatan memiliki nilai 1.7, Stimulasi memiliki nilai 2, dan Kebaruan memiliki nilai 1.3. Hasil analisa untuk kualitas pragmatic dan hedonis pun memiliki penilaian yang baik masing-masing memiliki nilai rata-rata 1.72 dan 1.73. Dan analisa benchmark juga memberikan nilai 1.73 yang dikatakan baik. Analisa dengan menggunakan UEQ menunjukkan user experience dari pengguna PaTik Bali dapat dikatakan baik dengan nilai rata-rata diatas 1.
\end{abstract}

Kata kunci: user experience, UEQ, PaTik Bali, keyboard virtual

\section{USER EXPERIENCE ANALYSIS AND EVALUATION PATIK BALI WITH THE USER EXPERIENCE QUESTIONNAIRE (UEQ) METHOD}

\begin{abstract}
PaTik Bali is a mobile-based virtual keyboard application. PaTik keyboard functions to write Balinese script. PaTik has an autocorrection feature in accordance with the Balinese script. On the Google Play Store, the number of devices installed is more than 89,000 mobile. In this study, we want to know the level of user comfort in terms of User Experience. So in this study an evaluation of the experience of PaTik Bali users was conducted. The evaluation was carried out using the User Experience Questionnaire (UEQ) method. Completeness of aspects, namely attractiveness, pragmatic quality and hedonic quality are the advantages of User Experience Questionnaire (UEQ). In addition, Data Analysis Tool has been provided in Excel format to facilitate the measurement of User Experience Questionnaire (UEQ). The evaluation was carried out on a population of 34 data. The User Experience Questionnaire (UEQ) evaluation has a good rating. Attraction has an average value of 1.8, clarity has a value of 1.7, Efficiency has a value of 1.6, Accuracy has a value of 1.7, Stimulation has a value of 2, and Novelty has a value of 1.3. The analysis results for pragmatic and hedonic quality also have good ratings, each having an average value of 1.72 and 1.73. And benchmark analysis also gives a value of 1.73 which is said to be good. Analysis using UEQ shows that the user experience of PaTik Bali users can be said to be good with an average value above 1
\end{abstract}

Keywords: user experience, UEQ, PaTik Bali, virtual keyboard

\section{PENDAHULUAN}

PaTik Bali merupakan aplikasi keyboard virtual. Keyboard virtual dibuat berbasis mobile.
Mobile apps merupakan sarana termudah bagi orang awam untuk mendapatkan atau mengakses informasi kapan pun dan dimanapun(Putra et al., 2019). 
Aplikasi mobile berbasis android adalah aplikasi yang paling banyak digunakan (STATCOUNTER, 2018). Berdasarkan hal tersebut PaTik Bali dibuat dalam sistem operasi Android. PaTik merupakan keyboard yang berfungsi untuk menuliskan aksara bali. Aplikasi PaTik sudah dapat di unduh melalui google playstore pada perangkat android. Lebih dari 50.000 perangkat telah terinstall PaTik Bali. Berkaitan dengan aturan penulisan aksara bali, PaTik memiliki fitur autocorrection apabila ada kesalahan dalam penulisan aksara bali (Iswara, Santika and Wijaya, 2019c).

Berdasarkan google playstore, jumlah perangkat terinstall mencapai lebih dari 89.000 sampai tahun 2019, namun dibalik itu perngkat yang menguninstall juga mencapai jumlah 82.000 perangkat. Banyaknya jumlah yang menguninstall bisa saja disebabkan ketidaknyamanan pengguna dari segi User Interface (UI) ataupun User Experience $(U X)$. Untuk mendapatkan pengalaman pengguna yang baik, aplikasi harus mudah dipelajari, efisien, mudah digunakan, dan atraktif (Hinderks et al., 2019). Belum dilakukan evaluasi tentang pengalaman pengguna dari user interface yang dirancang(Iswara, Santika and Wijaya, 2019b). Sehingga belum diketahui tingkat pengalaman pengguna PaTik Bali.

Uji UX perlu dilakukan untuk kesuksesan sebuah desain UI (Susilo, Wijaya and Hartanto, 2018). UX yang baik akan mendukung interaksi yang baik antara user dengan sistem (Santoso et al., 2016). Sesuai dengan fokus dari UX, yaitu bagaimana kerja suatu produk dari luar saat seseorang datang untuk melakukan kontak dengan produk tersebut (Santoso, Virginia and Susanto, 2017). Selain itu, UX juga berfokus pada user dan respon baik user terhadap sistem hal tersebut dapat dilihat dari emosi, perilaku dan nilai yang dihasilkan dari interaksi dengan sistem tersebut (Mustikaningtyas, Saputra and Pinandito, 2016). Evaluasi yang dilakukan hendaknya dapat dilakukan dengan cepat dan mudah. Berdasarkan hal-hal tersebut, maka dapat dilakukan evaluasi User Experience Quetionaire (UEQ), evaluasi yang bersifat gratis dan memberikan penilaian secara menyeluruh dengan cepat pada user experience (Kadastik, Artla and Schrepp, 2018).

UEQ merupakan bagian dari tes kegunaan klasik untuk mendapatkan kesan komprehensif UX dari aspek kegunaan dan aspek pengalaman (Santoso et al., 2016). UEQ memungkinkan penilaian yang cepat atas pengalaman pengguna produk interaktif (Sularsa and Prihatmanto, 2015). Dengan kata lain, UEQ memberikan pengukuran aspek teknis dan non teknis terkait emosi atau persepsi kesenangan pengguna (Intanny et al., 2018). Kelengkapan aspek, yaitu attractiveness, pragmatic quality dan hedonic quality menjadi keunggulan UEQ dibanding tool yang lain. Selain itu, ketersediaan template berupa Data Analysist Tool dalam format excell dalam mengukur UX memudahkan penggunaan alat ukur UEQ (Santosa and Winarno, 2019). Hasil dari pengukuran UEQ dapat digunakan sebagai referensi pengingkatan kualitas user interface (Paramitha, Dantes and Indrawan, 2018).

Berdasarkan permasalahan tersebut maka dilakuakan evaluasi UX dari aplikasi keyboard virtual PaTik. Diharapkan dengan evaluasi yang dilakukan dapat memberikan kekukarangan yang dimiliki aplikasi PaTik.

\section{METODE PENELITIAN}

Penelitin ini menggunakan metode UEQ dengan melalui beberapa tahapan yang dapat dilihat pada gambar 1. Untuk metode UEQ sendiri merupakan suatu metode yang dibuat oleh Schrepp dengan memberikan pengukuran dari beberapa skala yang dijelaskan lebih detail pada poin (d.).

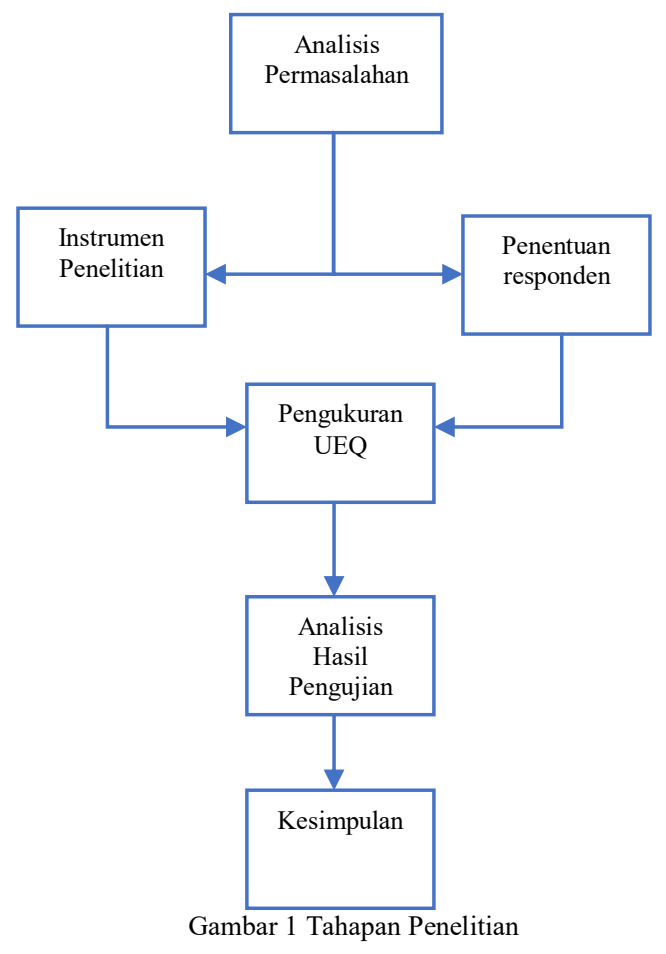

\section{a. Analisis Permasalahan}

Dalam penelitian ini, objek penelitian adalah aplikasi PaTik Bali. Aplikasi keyboard virtual yang dapat diinstall pada perangkat smartphone android. PaTik Bali merupakan keyboard untuk Penelitian ini merupakan penelitian dengan metode kuantitaif untuk mengukur UX dalam menggunakan aplikasi PaTik.

\section{b. Instrumen Penelitian}

Instrumen penelitian menggunakan kuesioner UEQ. UEQ kuesioner terdiri dari 26 item. Ke 26 item tersebut dikutip dari penelitian (Santosa and Winarno, 2019) dapat dilihat pada gambar 2. 


\begin{tabular}{|c|c|c|c|c|c|c|c|c|c|}
\hline & & 1 & 2 & 3 & 4 & 5 & 6 & 7 & \\
\hline 1 & menyusahkan & 0 & 0 & 0 & 0 & 0 & 0 & 0 & menyenangkan \\
\hline 2 & tak dapat dipahami & 0 & 0 & 0 & 0 & 0 & 0 & 0 & dapat dipahami \\
\hline 3 & kreatif & 0 & 0 & 0 & 0 & 0 & 0 & 0 & monoton \\
\hline 4 & mudah dipelajari & 0 & 0 & 0 & 0 & 0 & 0 & 0 & sulit dipelajari \\
\hline 5 & bermanfaat & 0 & 0 & 0 & 0 & 0 & 0 & 0 & kurang bermanfaat \\
\hline 6 & membosankan & 0 & 0 & 0 & 0 & 0 & 0 & 0 & mengasyikkan \\
\hline 7 & tidak menarik & 0 & 0 & 0 & 0 & 0 & 0 & 0 & menarik \\
\hline 8 & tak dapat diprediksi & 0 & 0 & 0 & 0 & 0 & 0 & 0 & dapat diprediksi \\
\hline 9 & cepat & 0 & 0 & 0 & 0 & 0 & 0 & 0 & lambat \\
\hline 10 & berdaya cipta & 0 & 0 & 0 & 0 & 0 & 0 & 0 & konvensional \\
\hline 11 & menghalangi & 0 & 0 & 0 & 0 & 0 & 0 & 0 & mendukung \\
\hline 12 & baik & 0 & 0 & 0 & 0 & 0 & 0 & 0 & buruk \\
\hline 13 & rumit & 0 & 0 & 0 & 0 & 0 & 0 & 0 & sederhana \\
\hline 14 & tidak disukai & 0 & 0 & 0 & 0 & 0 & 0 & 0 & menggembirakan \\
\hline 15 & lazim & 0 & 0 & 0 & 0 & 0 & 0 & 0 & terdepan \\
\hline 16 & tidak nyaman & 0 & 0 & 0 & 0 & 0 & 0 & 0 & nyaman \\
\hline 17 & aman & 0 & 0 & 0 & 0 & 0 & 0 & 0 & tidak aman \\
\hline 18 & memotivasi & 0 & 0 & 0 & 0 & 0 & 0 & 0 & tidak memotivasi \\
\hline 19 & memenuhi ekspektasi & 0 & 0 & 0 & 0 & 0 & 0 & 0 & tidak memenuhi ekspektasi \\
\hline 20 & tidak efisien & 0 & 0 & 0 & 0 & 0 & 0 & 0 & efisien \\
\hline 21 & jelas & 0 & 0 & 0 & 0 & 0 & 0 & 0 & membingungkan \\
\hline 22 & tidak praktis & 0 & 0 & 0 & 0 & 0 & 0 & 0 & praktis \\
\hline 23 & terorganisasi & 0 & 0 & 0 & 0 & 0 & 0 & 0 & berantakan \\
\hline 24 & atraktif & 0 & 0 & 0 & 0 & 0 & 0 & 0 & tidak atraktif \\
\hline 25 & ramah pengguna & 0 & 0 & 0 & 0 & 0 & 0 & 0 & tidak ramah pengguna \\
\hline 26 & konservatif & 0 & 0 & 0 & 0 & 0 & 0 & 0 & inovatif \\
\hline
\end{tabular}

\section{c. Penentuan Responden}

Evaluasi UEQ dilakukan kepada pengguna aplikasi PaTik. Kuisioner diberikan kepada 20 hingga 30 pengguna. Penentuan jumlah responden sudah dapat memberikan hasil yang cukup stabil. Hal tersebut telah dilakukan pada penelitian sejenis. Sehingga memenuhi syarat responden UEQ yang seharusnya (Schrepp, 2015). Versi asli UEQ dirancang dalam bahasa Jerman, tetapi sejauh ini telah diterjemahkan ke beberapa bahasa seperti Spanyol dan Portugis (Suastini et al., 2018).

\section{d. Pengukuran UEQ}

Pengukuran User Experience dilakukan untuk mengetahui pengalaman pengguna aplikasi PaTik. Pengukuran dilakukan dengan metode UEQ. Seluruh instrumen UEQ digunakan dalam penelitian ini. Awalnya lebih dari 200 item yang memiliki relasi dengan UX dibuat oleh usability experts dalam dua sesi brainstorming untuk digunakan sebagai instrumen UEQ (Schrepp, Hinderks and
Thomaschewski, 2017). Struktur dari UEQ dapat dilihat pada gambar 3 .

Pada gambar 1 ditunjukkan terdapat enam (6) skala yang dapat dikelompokkan dari dua puluh enam (26) item pertanyaan. Enam skala tersebut dalam (Schrepp, 2015)adalah:

a. Attractiveness (daya tarik): Impresi umum peng- guna atas produk, suka atau tidak suka.

b. Perspicuity (Kejelasan): Seberapa besar kejelasan dari sebuah produk. Misal: mudah dipahami atau sulit dipahami.

c. Efficiency (Efisiensi): Seberapa besar pengguna dapat menyelesaikan tugasnya tanpa usaha yang besar atau efisien. Misal: cepat atau lambat, praktis atau tidak praktis.

d. Dependability (Ketepatan): apakah pengguna me- rasa dapat mengontrol interaksi? Misal: dapat di- prediksi atau tidak dapat diprediksi, mendukung atau menghalangi.

e. Stimulation (Stimulasi): Seberapa besar motivasi untuk menggunakan produk. Misal: bermanfaat atau kurang bermanfaat, menarik atau tidak menarik. 


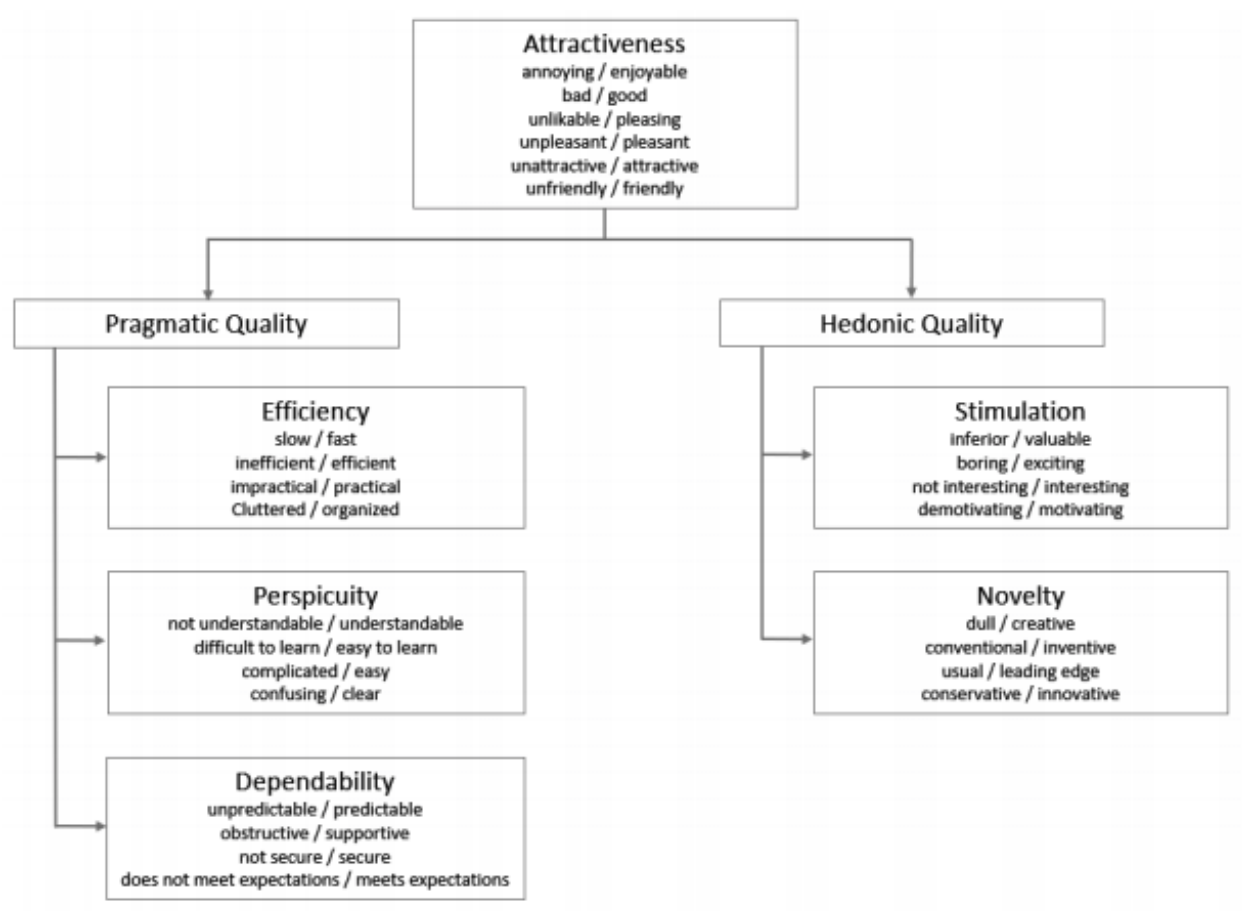

Gambar 3. Skala Struktur UEQ(Schrepp, 2015)

f. Novelty (Kebaruan): Seberapa besar kebaruan dari produk. Misal: kreatif atau tidak kreatif, konser- vatif atau inovatif.

\section{HASIL DAN PEMBAHASAN}

PaTik Bali hanya memliki sebuah layer. Dimana ketika user ingin memilih aksara gantungan atau gempelan, user hanya butuh menekan lama dan memilih bentung gantungan yang diinginkan. Layout yang di terapkan pada PaTik Bali didisain agar mampu menyatukan letak dari aksara yang memiliki ucapan yang sama, misal aksara ta yang terlihat pada Gambar 3. ketika aksara ta ditekan lama maka akan muncul beberapa bentuk ta yang lainnya. Bentuk yang ada pada popup keyboard PaTik untuk ta adalah berupa gantungan ta, talatik, gantungan talatik, tatawa dan gantungan tatawa, begitu juga dengan aksara yang lainnya. Aksara bali memiliki banyak bentuk dengan pengucapan yang sama seperti $s a$, menjadi gempelan sasapa, sasaga, gantungan sesaga, gempelan $s a$ (Iswara, Santika and Wijaya, 2019a). Jadi layout yang dirancang memang diharapkan untuk menghidari kebingungan para pengguna, karena sudah di golongkan dalam satu aksara yang serupa dan dimunculkan dalam bentuk рорир seperti terlihat pada Gambar 4.

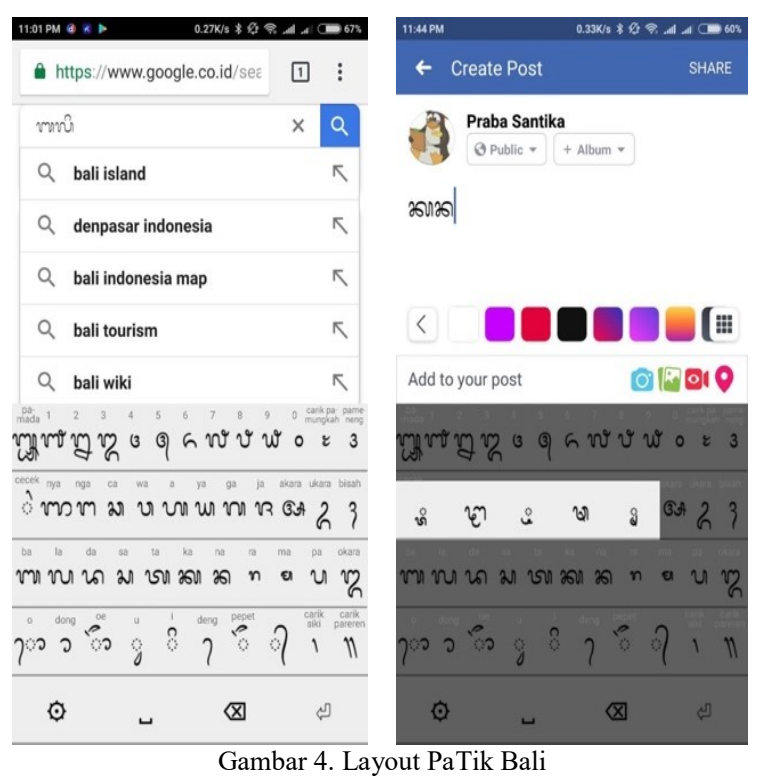

Pelaksanaan evaluasi PaTik Bali dilakukan dengan UEQ kuesioner. UEQ disebarkan kepada 42 responden. Experience yang diperhatikan pada PaTik adalah konsep layer yang digunakan pada keyboard. Dari 42 responden hanya digunakan 34 data responden karena tingkat inkonsistensi yang cukup tinggi. Untuk hasil sebaran kuesioner dapat dilihat pada tabel 1 . 
Tabel 1. Data Respon UEQ

\begin{tabular}{|c|c|c|c|c|c|c|c|c|c|c|c|c|c|c|c|c|c|c|c|c|c|c|c|c|c|}
\hline \multicolumn{26}{|c|}{ Items } \\
\hline 1 & 2 & 3 & 4 & 5 & 6 & 7 & 8 & 9 & 10 & 11 & 12 & 13 & 14 & 15 & 16 & 17 & 18 & 19 & 20 & 21 & 22 & 23 & 24 & 25 & 26 \\
\hline 7 & 7 & 4 & 1 & 1 & 6 & 7 & 6 & 1 & 1 & 7 & 1 & 7 & 7 & 4 & 7 & 2 & 2 & 1 & 6 & 2 & 6 & 1 & 1 & 2 & 6 \\
\hline 7 & 7 & 4 & 1 & 1 & 7 & 7 & 7 & 1 & 1 & 7 & 1 & 7 & 7 & 4 & 7 & 1 & 1 & 1 & 6 & 2 & 6 & 1 & 1 & 2 & 6 \\
\hline 6 & 6 & 3 & 1 & 1 & 4 & 4 & 6 & 3 & 3 & 7 & 2 & 7 & 5 & 4 & 6 & 1 & 2 & 3 & 4 & 3 & 6 & 2 & 2 & 3 & 7 \\
\hline 5 & 6 & 2 & 3 & 1 & 6 & 5 & 5 & 1 & 2 & 6 & 1 & 3 & 5 & 5 & 5 & 2 & 2 & 2 & 5 & 4 & 5 & 4 & 3 & 2 & 6 \\
\hline 3 & 4 & 7 & 3 & 3 & 4 & 4 & 5 & 4 & 4 & 4 & 4 & 4 & 4 & 4 & 4 & 3 & 2 & 4 & 5 & 3 & 5 & 3 & 4 & 3 & 6 \\
\hline 5 & 5 & 1 & 2 & 1 & 5 & 7 & 5 & 2 & 1 & 5 & 2 & 4 & 5 & 5 & 5 & 2 & 1 & 3 & 5 & 3 & 6 & 5 & 2 & 5 & 7 \\
\hline 3 & 5 & 2 & 3 & 1 & 6 & 6 & 5 & 4 & 3 & 7 & 1 & 4 & 5 & 6 & 5 & 3 & 1 & 2 & 5 & 2 & 5 & 3 & 4 & 4 & 6 \\
\hline 4 & 5 & 3 & 4 & 1 & 5 & 7 & 4 & 3 & 3 & 7 & 3 & 4 & 5 & 6 & 5 & 3 & 1 & 4 & 5 & 2 & 3 & 3 & 3 & 4 & 7 \\
\hline 7 & 5 & 4 & 4 & 1 & 5 & 5 & 5 & 3 & 4 & 5 & 2 & 4 & 5 & 5 & 5 & 3 & 3 & 3 & 6 & 3 & 5 & 3 & 4 & 3 & 6 \\
\hline 6 & 6 & 6 & 4 & 4 & 4 & 5 & 5 & 3 & 5 & 6 & 3 & 5 & 5 & 6 & 6 & 2 & 3 & 3 & 7 & 1 & 7 & 2 & 1 & 1 & 7 \\
\hline 6 & 6 & 3 & 1 & 1 & 7 & 7 & 7 & 1 & 1 & 7 & 1 & 7 & 7 & 1 & 7 & 1 & 1 & 1 & 7 & 1 & 7 & 1 & 1 & 1 & 7 \\
\hline 7 & 7 & 2 & 2 & 1 & 6 & 7 & 6 & 2 & 1 & 6 & 1 & 6 & 6 & 7 & 6 & 1 & 1 & 1 & 6 & 2 & 6 & 6 & 1 & 1 & 6 \\
\hline 5 & 4 & 5 & 5 & 5 & 5 & 4 & 4 & 5 & 3 & 3 & 5 & 6 & 6 & 5 & 5 & 6 & 5 & 5 & 6 & 6 & 5 & 5 & 5 & 5 & 5 \\
\hline 7 & 7 & 1 & 1 & 1 & 7 & 7 & 7 & 1 & 1 & 7 & 1 & 7 & 7 & 7 & 7 & 1 & 1 & 1 & 7 & 1 & 7 & 1 & 1 & 1 & 6 \\
\hline 7 & 7 & 1 & 1 & 1 & 7 & 7 & 7 & 1 & 1 & 7 & 1 & 7 & 7 & 7 & 7 & 1 & 1 & 1 & 7 & 1 & 7 & 1 & 1 & 1 & 7 \\
\hline 6 & 6 & 2 & 2 & 2 & 6 & 6 & 6 & 2 & 2 & 6 & 2 & 6 & 6 & 6 & 6 & 2 & 2 & 2 & 6 & 2 & 6 & 2 & 2 & 2 & 6 \\
\hline 5 & 7 & 1 & 1 & 1 & 7 & 7 & 7 & 1 & 1 & 7 & 1 & 7 & 6 & 7 & 7 & 1 & 1 & 1 & 7 & 1 & 7 & 1 & 1 & 1 & 7 \\
\hline 7 & 6 & 1 & 1 & 1 & 6 & 5 & 6 & 2 & 3 & 6 & 1 & 6 & 6 & 4 & 6 & 6 & 1 & 2 & 6 & 1 & 7 & 1 & 2 & 2 & 7 \\
\hline 6 & 5 & 2 & 2 & 2 & 6 & 6 & 7 & 2 & 2 & 7 & 1 & 7 & 6 & 6 & 6 & 4 & 2 & 2 & 6 & 2 & 6 & 3 & 2 & 2 & 6 \\
\hline 7 & 7 & 1 & 1 & 1 & 6 & 7 & 6 & 1 & 3 & 6 & 1 & 7 & 6 & 3 & 6 & 1 & 1 & 2 & 7 & 1 & 7 & 1 & 3 & 1 & 6 \\
\hline 6 & 7 & 1 & 2 & 1 & 6 & 7 & 6 & 1 & 3 & 6 & 1 & 6 & 6 & 2 & 7 & 1 & 1 & 1 & 6 & 1 & 6 & 3 & 3 & 2 & 6 \\
\hline 7 & 6 & 4 & 1 & 1 & 7 & 7 & 6 & 4 & 4 & 6 & 1 & 7 & 6 & 6 & 7 & 1 & 1 & 1 & 6 & 4 & 6 & 2 & 3 & 1 & 6 \\
\hline 6 & 6 & 1 & 1 & 1 & 6 & 7 & 4 & 1 & 2 & 6 & 1 & 6 & 6 & 6 & 6 & 2 & 1 & 1 & 6 & 1 & 6 & 1 & 1 & 1 & 6 \\
\hline 5 & 6 & 5 & 3 & 3 & 6 & 6 & 6 & 3 & 6 & 6 & 2 & 6 & 5 & 5 & 6 & 2 & 2 & 2 & 5 & 3 & 6 & 2 & 2 & 2 & 6 \\
\hline 7 & 7 & 1 & 1 & 1 & 7 & 7 & 1 & 1 & 1 & 7 & 1 & 7 & 7 & 7 & 7 & 1 & 1 & 3 & 6 & 2 & 7 & 1 & 1 & 1 & 7 \\
\hline 7 & 7 & 1 & 1 & 1 & 7 & 7 & 2 & 4 & 4 & 6 & 1 & 7 & 7 & 7 & 7 & 1 & 1 & 1 & 7 & 1 & 7 & 1 & 3 & 1 & 7 \\
\hline 7 & 5 & 1 & 2 & 1 & 7 & 6 & 4 & 3 & 4 & 7 & 1 & 4 & 5 & 5 & 7 & 1 & 1 & 4 & 4 & 2 & 7 & 5 & 4 & 3 & 7 \\
\hline 5 & 5 & 4 & 2 & 1 & 5 & 6 & 5 & 3 & 4 & 7 & 2 & 5 & 5 & 4 & 6 & 1 & 1 & 2 & 6 & 2 & 7 & 5 & 3 & 4 & 6 \\
\hline 4 & 4 & 1 & 4 & 3 & 5 & 6 & 5 & 3 & 2 & 6 & 1 & 3 & 4 & 4 & 6 & 1 & 1 & 4 & 5 & 4 & 4 & 4 & 4 & 3 & 1 \\
\hline 4 & 4 & 4 & 5 & 7 & 2 & 3 & 5 & 3 & 4 & 4 & 5 & 3 & 3 & 2 & 4 & 3 & 5 & 3 & 3 & 2 & 5 & 4 & 2 & 3 & 2 \\
\hline 4 & 4 & 5 & 4 & 5 & 4 & 5 & 4 & 4 & 4 & 4 & 4 & 4 & 4 & 4 & 4 & 4 & 4 & 4 & 4 & 4 & 4 & 5 & 4 & 4 & 4 \\
\hline
\end{tabular}

Tabel 1 merupakan tabel data isian yang diberikan oleh 34 responden. Data tersebut merupakan data yang sudah diseleksi berdasarkan tingkat konsistensinya. Konsistensi yang dilihat adalah apakah responden menjawab asal-asalan atau tidak. Data pada tabel 1 kemudian ditransformasikan untuk mengetahui nilai negatif dan positif dari setiap item. Data hasil transformasi dapat dilihat pada tabel 2.

Tabel 2. Data Transformasi Respon UEQ

\begin{tabular}{|c|c|c|c|c|c|c|c|c|c|c|c|c|c|c|c|c|c|c|c|c|c|c|c|c|c|}
\hline \multirow[b]{2}{*}{1} & \multicolumn{25}{|c|}{ Items } \\
\hline & 2 & 3 & 4 & 5 & 6 & 7 & 8 & 9 & 10 & 11 & 12 & 13 & 14 & 15 & 16 & 17 & 18 & 19 & 20 & 21 & 22 & 23 & 24 & 25 & 26 \\
\hline 3 & 3 & 0 & 3 & 3 & 2 & 3 & 2 & 3 & 3 & 3 & 3 & 3 & 3 & 0 & 3 & 2 & 2 & 3 & 2 & 2 & 2 & 3 & 3 & 2 & 2 \\
\hline 3 & 3 & 0 & 3 & 3 & 3 & 3 & 3 & 3 & 3 & 3 & 3 & 3 & 3 & 0 & 3 & 3 & 3 & 3 & 2 & 2 & 2 & 3 & 3 & 2 & 2 \\
\hline 2 & 2 & 1 & 3 & 3 & 0 & 0 & 2 & 1 & 1 & 3 & 2 & 3 & 1 & 0 & 2 & 3 & 2 & 1 & 0 & 1 & 2 & 2 & 2 & 1 & 3 \\
\hline $\begin{array}{l}1 \\
-\end{array}$ & 2 & 2 & 1 & 3 & 2 & 1 & 1 & 3 & 2 & 2 & 3 & -1 & 1 & 1 & 1 & 2 & 2 & 2 & 1 & 0 & 1 & 0 & 1 & 2 & 2 \\
\hline 1 & 0 & -3 & 1 & 1 & 0 & 0 & 1 & 0 & 0 & 0 & 0 & 0 & 0 & 0 & 0 & 1 & 2 & 0 & 1 & 1 & 1 & 1 & 0 & 1 & 2 \\
\hline
\end{tabular}




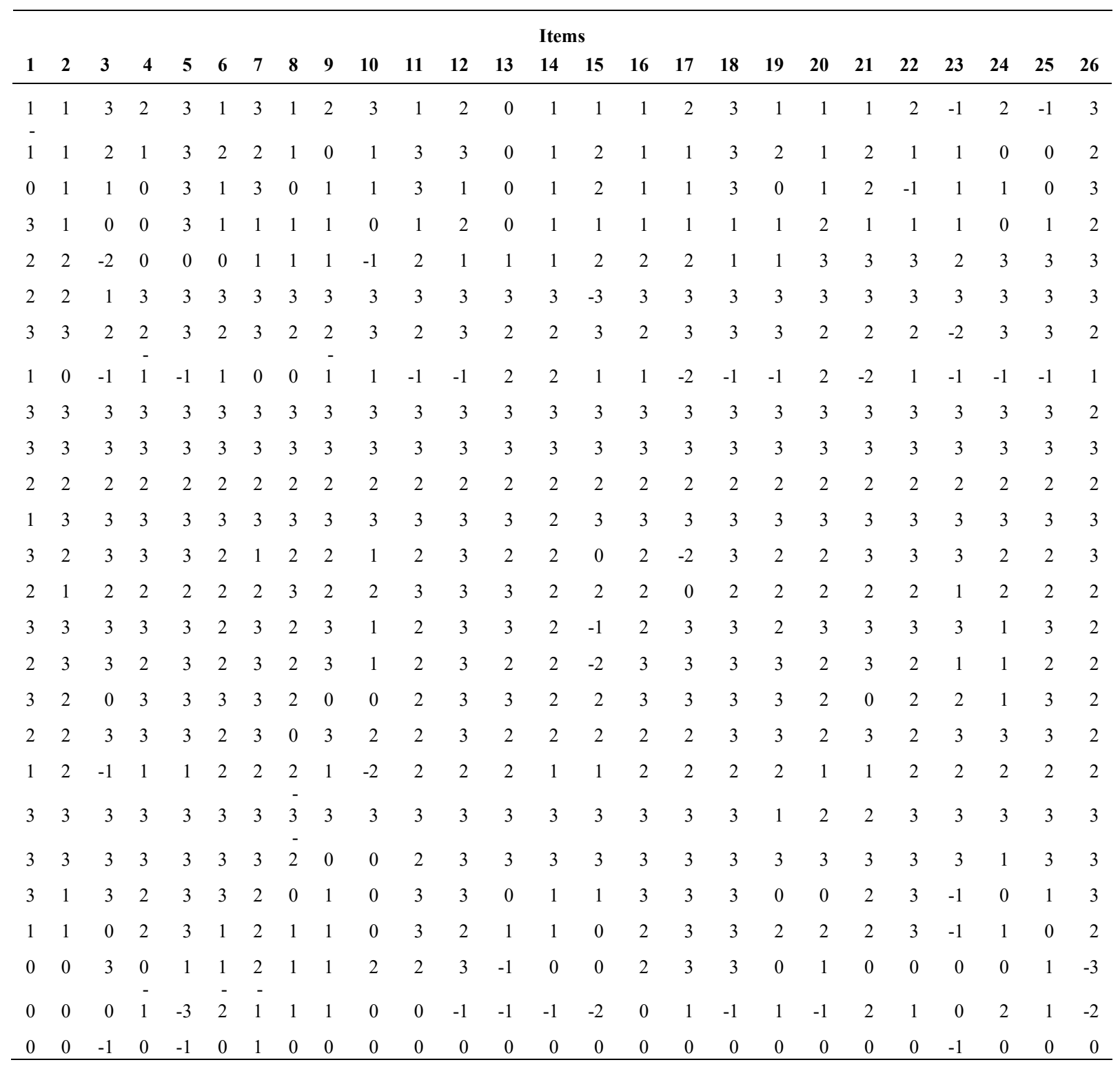

Data hasil tranformasi pada tabel 2 kemudian dikelompokkan berdasarkan enam skala. Keenam skala tersebut adalah daya tarik, kejelasan, efisiensi, ketepatan, stimulasi, dan kebaruan. Keenam skala tersebut dapat dilihat pada Tabel 3.

Tabel 3. Hasil Rataan, Varian, dan Simpangan Baku

\begin{tabular}{cccccccc}
\hline Item & Mean & Variance & Std. Dev. & No. & Left & Right & Scale \\
\hline 1 & 1.7 & 1.7 & 1.3 & 31 & menyusahkan & menyenangkan & Daya tarik \\
2 & 1.8 & 1.2 & 1.1 & 31 & tak dapat dipahami & dapat dipahami & Kejelasan \\
3 & 1.3 & 3.1 & 1.8 & 31 & kreatif & monoton & Kebaruan \\
4 & 1.8 & 1.8 & 1.3 & 31 & mudah dipelajari & sulit dipelajari & Kejelasan \\
5 & 2.2 & 2.4 & 1.5 & 31 & bermanfaat & kurang bermanfaat & Stimulasi \\
6 & 1.7 & 1.5 & 1.2 & 31 & membosankan & mengasyikkan & Stimulasi \\
7 & 2.0 & 1.4 & 1.2 & 31 & tidak menarik & menarik & Stimulasi \\
8 & 1.3 & 2.0 & 1.4 & 31 & tak dapat diprediksi & dapat diprediksi & Ketepatan \\
9 & 1.6 & 1.5 & 1.2 & 31 & cepat & lambat & Efisiensi \\
10 & 1.3 & 2.0 & 1.4 & 31 & berdaya cipta & konvensional & Kebaruan \\
11 & 2.1 & 1.2 & 1.1 & 31 & menghalangi & mendukung & Ketepatan \\
12 & 2.2 & 1.5 & 1.2 & 31 & baik & buruk & Daya tarik \\
\hline
\end{tabular}




\begin{tabular}{cccccccc}
\hline Item & Mean & Variance & Std. Dev. No. & Left & Right & Scale \\
\hline 13 & 1.6 & 2.1 & 1.5 & 31 & rumit & sederhana & Kejelasan \\
14 & 1.6 & 1.1 & 1.1 & 31 & tidak disukai & menggembirakan & Daya tarik \\
15 & 1.0 & 2.6 & 1.6 & 31 & lazim & terdepan & Kebaruan \\
16 & 2.0 & 1.0 & 1.0 & 31 & tidak nyaman & nyaman & Daya tarik \\
17 & 1.9 & 2.0 & 1.4 & 31 & aman & tidak aman & Ketepatan \\
18 & 2.3 & 1.3 & 1.2 & 31 & memotivasi & tidak memotivasi & Stimulasi \\
19 & 1.7 & 1.5 & 1.2 & 31 & memenuhi ekspektasi & tidak memenuhi ekspektasi & Ketepatan \\
20 & 1.7 & 1.1 & 1.0 & 31 & tidak efisien & efisien & Efisiensi \\
21 & 1.8 & 1.5 & 1.2 & 31 & jelas & membingungkan & Kejelasan \\
22 & 1.9 & 1.1 & 1.1 & 31 & tidak praktis & praktis & Efisiensi \\
23 & 1.4 & 2.6 & 1.6 & 31 & terorganisasi & berantakan & Efisiensi \\
24 & 1.6 & 1.5 & 1.2 & 31 & atraktif & tidak atraktif & Daya tarik \\
25 & 1.7 & 1.6 & 1.3 & 31 & ramah pengguna & tidak ramah pengguna & Daya tarik \\
26 & 2.0 & 1.9 & 1.4 & 31 & konservatif & inovatif & Kebaruan \\
\hline
\end{tabular}

Berdasarkan Tabel 3, dapat dilihat hasil rataan, varian dan simpangan untuk ke 26 item UEQ. Nilai yang dimiliki setiap item memiliki kisaran diatas 1 . Penilaian tersebut memperlihatkan masing-masing item pertanyaan memiliki nilai yang baik. Data pada gambar tersebut menjadi acuan untuk melakukan perhitungan enam skala. Kemudian akan dilakukan analisa dan ditarik kesimpulan skala terbesar dan terkecil dari UEQ. Masing-masing skala memiliki beberapa pertanyaan pada 26 item tersebut. Skala tersebut dihitung untuk dicari nilai rata-ratanya. Nilai rata-rata diberikan pada gambar 6 .

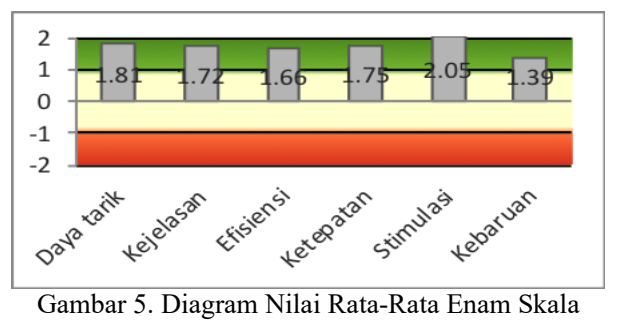

Gambar 5 merupakan grafik nilai rata-rata dari enam skala UEQ. Terlihat dengan jelas semua skala berada pada batas dengan warna hijau. Hal tersebut memberikan gambaran bahwa keseluruhan sekala pengukuran berada pada level yang baik. Komponen skala tersebut adalah daya tarik, kejelasan, Efisiensi, Ketepatan, Stimulasi, dan Kebaruan. Penilaian terbaik terdapat pada elemen stimulasi, sedangkan penilaian terendah terdapat pada poin kebaruan.

Komponen stimulasi dilihat dari item bermanfaat, mengasyikkan, menarik, dan memotivasi. Semua item mendapakan nilai di atas 1 yang msuk dalam taraf baik. Namun item yang mendapatkan nilai terendah adalah memotivasi. Untuk komponen kebaruan, nilai dilihat berdasarkan item kreatif, berdaya cipta, lazim, dan inovasi. Berdasarkan kuesioner, PaTik Bali memiliki tingkat inovasi yang sangat baik, hingga menyentuh angka 2. Namun memiliki penilaian terendah pada item lazim/terdepan. Namun apabila dilihat nilai terendah tersebut sudah termasuk dalam kategori baik.

Keenam skala tersebut dapat diolah untuk mengetahui Kualitas Pragmatic dan Hedonic dari aplikasi yang dievalusi. Kualitas pragmatic terdiri dari kejelasan, efisiensi, dan ketepatan. Stimulasi dan kebaruan menjadi bagian dari kualitas hedonic. Penilaian untuk daya tarik, kualitas pragmatic, dan hedonic dapat dilihat pada Tabel 4.

\begin{tabular}{lc}
\multicolumn{2}{c}{ Tabel 4. Kualitas Pragmatic dan Hedonic } \\
\hline \multicolumn{2}{c}{ Pragmatic and Hedonic Quality } \\
Daya tarik & 1.81 \\
Kualitas Pragmatis & 1.72 \\
Kualitas Hedonis & 1.73 \\
\hline
\end{tabular}

Dari ketiga kualitas tersebut, daya tarik memiliki nilai yang tertinggi. Berdasarkan Tabel 4 dapat dilihat nilai yang dimiliki daya tarik berkisar 1.81 yang sudah termasuk kategori bagus. Kemudian disusul dengan kualitas hedonis dan pragmatis dengan nilai secara berurutan 1.73 dan 1.72. Untuk memperjelas hal tersebut, maka dibuatkan grafik yang ditunjukkan pada gambar 6 .

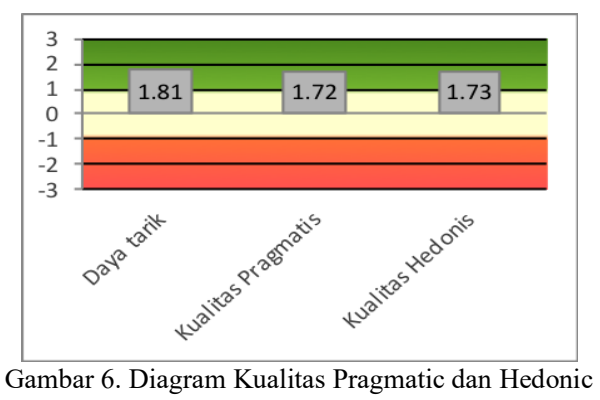


Gambar 6 menunjukkan penilaian yang diberikan untuk daya tarik, kualitas pragmatic, dan hedonis. Semua penilaian memberikan hasil dalam kategori baik. Hal tersebut dapat dilihat pada diagram batang. Puncak dari masing-masing diagram berada pada area yang berwarna hijau muda. Hijau muda menggambarkan penilaian yang baik, sedangkan hijau tua menggambarkan penilaian yang sangat baik.

Analisis lain yang dilakukan adalah analisis benchmark. Analisis tersebut membandingkan evaluasi penelitian ini dengan penelitian sejenis yang telah dilaporkan pada UEQ online. Benchmark untuk user experience PaTik bali dapat dilihat pada Tabel 9 dan Gambar 7. Tabel 5 menunjukkan posisi penilaian UEQ PaTik Bali dibandingkan dengan penilitian sejenis. Berdasarkan Tabel 5, nilai tertinggi berada pada stimulasi dan nilai terendah berada pada skala kebaruan.

Tabel 5.Benchmark Evaluasi PaTik Bali

\begin{tabular}{llll}
\multicolumn{1}{c}{ Scale } & Mean & \multicolumn{1}{c}{ Comparisson to benchmark } & \multicolumn{1}{c}{ Interpretation } \\
Daya tarik & 1.81 & Excellent & $10 \%$ of results better, 75\% of results worse \\
Kejelasan & 1.73 & Good & $25 \%$ of results better, 50\% of results worse \\
Efisiensi & 1.66 & Good & $10 \%$ of results better, 75\% of results worse \\
Ketepatan & 1.76 & Excellent & In the range of the 10\% best results \\
Stimulasi & 2.06 & Excellent & In the range of the 10\% best results \\
Kebaruan & 1.40 & Good & $10 \%$ of results better, 75\% of results worse \\
\hline
\end{tabular}

Bentuk penilaian tersebut kemudian dibuatkan diagram untuk mempermudah pengamatan penilaian

masing-masing skala. Diagram benchmark untuk PaTik Bali dapat dilihat pada gambar 7.

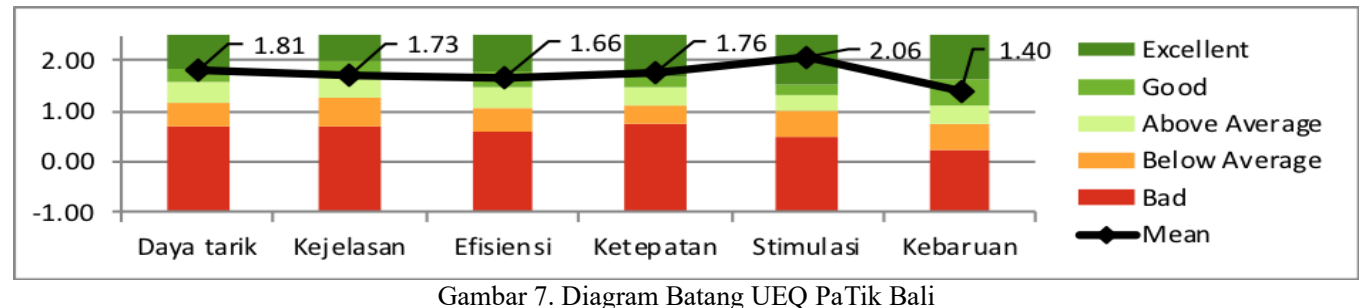

Gambar 7 menunjukkan benchmark penilaian PaTik Bali. Berdasarkan gambar 7, empat kelas memiliki nilai baik dan dua kelas memiliki nilai sangat baik. Nilai sangat baik dimiliki oleh kelas ketepatan dan stimulasi. Sedanngkan empat penilaian baik dimiliki oleh daya tarik, kejelasan, efisiensi, dan kebaruan.

\section{KESIMPULAN}

Berdasarkan analisa yang dihasilkan pada bagian pembahasan dapat diberikan suatu kesimpulan. Dari 26 item pertanyaan UEQ dikelompokkan menjadi enam kelas. Penilaian dari keenam kelas tersebut memiliki penilaian yang baik. Hasil analisa untuk kualitas pragmatic dan hedonis pun memiliki penilaian yang baik. Dan analisa benchmark juga memberikan nilai baik. Berdasarkan hal tersebut user experience yang dialami pengguna PaTik Bali dapat dikatakan baik. Dengan kata lain penyebab banyaknya pengguna yanng menguninstall PaTik Bali bukan karena pengalaman pengguna yang buruk ketika menggunakan aplikasi tersebut.

\section{DAFTAR PUSTAKA}

HINDERKS, A., SCHREPP, M., DOMÍNGUEZ
MAYO, F.J., ESCALONA, M.J. AND THOMASCHEWSKI, J., 2019. Developing a UX KPI based on the user experience questionnaire. Computer Standards and Interfaces Science Direct, [online] 65(January), pp.38-44. Available at: $<$ https://doi.org/10.1016/j.csi.2019.01.007>.

INTANNY, V., WIDIYASTUTI, I., DOLOROSA, M. AND PERDANI, K., 2018. Pengukuran Kebergunaan dan Pengalaman Pengguna Marketplace Jogjaplaza . id dengan Metode UEQ dan USE Questionnaire. Pekommas, [online] 3(2), pp.117-126. Available at: $<$ https://media.neliti.com/media/publication s/267627-measuring-usability-and-userexperience-a292205a.pdf $>$.

ISWARA, I.B.A.I., SANTIKA, P.P. AND WIJAYA, I.N.S.W., 2019a. An Algorithm for AutoCorrection in PaTik Bali Using Pasang Pageh Aksara Wianjana. In: 2019 5th International Conference on New Media Studies. Badung: CONMEDIA.

ISWARA, I.B.A.I., SANTIKA, P.P. AND WIJAYA, I.N.S.W., 2019b. Design and Development Key Board For Aksara Bali On Android With Auto Parts Improvement. 
International Journal of Application Computer Science and Informatic Engineering (ACSIE), 1(2), pp.65-74.

ISWARA, I.B.A.I., SANTIKA, P.P. AND WIJAYA, I.N.S.W., 2019c. Google Play Store.

IZABAL, S.V., AKNURANDA, I. AND AZZAHRA, H.M., 2018. Evaluasi dan Perbaikan User Experience Menggunakan User Experience Questionnaire ( UEQ ) dan Focus Group Discussion ( FGD ) pada Situs Web FILKOM Apps Mahasiswa Fakultas Ilmu Komputer Universitas Brawijaya. Jurnal Pengembangan Teknologi Informasi dan Ilmu Komputer (J-PTIIK) Universitas Brawijaya, 2(9), pp.3224-3232.

KADASTIK, J., ARTLA, T. AND SCHREPP, M., 2018. Your Experience is Important! The User Experience Questionnaire (UEQ) Estonian Version. Rural environment. Education. Personality. (REEP) : proceedings of the 11th International scientific conference, 11(May), pp.281287.

MUSTIKANINGTYAS, B.A., SAPUTRA, M.C. AND PINANDITO, A., 2016. Analisis Usability Pada Website Universitas Brawijaya Dengan Heuristic Evaluation. Jurnal Teknologi Informasi dan Ilmu Komputer, 3(3), p.188.

PANGETSU, H., 2014. Usability Testing of Virtual Keyboard. International Journal of Communication \& Information Technology (CommIT) h, 8(1), pp.17-21.

PARAMITHA, A.A.I.I., DANTES, G.R. AND INDRAWAN, G., 2018. The evaluation of web based academic progress information system using heuristic evaluation and user experience questionnaire (UEQ). In: Proceedings of the 3rd International Conference on Informatics and Computing, ICIC 2018. IEEE.pp.1-6.

PUTRA, D.A., SANAPIAH, M.D.S., HANIFAH, A.I. AND AFIRIANTO, T., 2019. SEED (Stoke Disease Early Detection Application) - Rancang Bangun Aplikasi Mobile Berbasis Android Untuk Mendiagnosis Gejala Dini Penyakit Stroke Menggunakan K-Nearest Neighbor (K-Nn). Jurnal Teknologi Informasi Dan ILMU KOMPUTER, 6(3), P.287.

SANTOSA, P.I. AND WINARNO, W.W., 2019. Evaluasi User Experience pada Sistem Informasi Pasar Kerja Menggunakan User Experience Questionnare ( UEQ ). In: The 10th National Conference on Information Technology and Electrical Engineering. [online] Yogyakarta.pp.24-25. Available at:
$<$ http://citee.ft.ugm.ac.id/home.php?main= $\mathrm{M} 2 \mathrm{Z} 4 \mathrm{Vw} \% 3 \mathrm{D} \% 3 \mathrm{D}=$ \&part=REQ $\% 3 \mathrm{D}=>$.

SANTOSO, H.B., SCHREPP, M., ISAL, R.Y.K.., UTOMO, A.Y. AND PRIYOGI, B., 2016. Measuring user experience of the studentcentered E-learning environment. Journal of Educators Online, 13(1), pp.1-79.

SANTOSO, N.A., VIRGINIA, G. AND SUSANTO, B., 2017. Evaluation Interface Design to Build User Experience on SInTA Service Christian Duta Wacana University Yogyakarta. Transformatika, [online] 15(1), pp.26-35. Available at: <www.ueqonline.org.>.

SCHREPP, M., 2015. User Experience Questionnaire Handbook. Version 7 ed. [online] Available at: <http://www.ueqonline.org/>.

SCHREPP, M., HINDERKS, A. AND THOMASCHEWSKI, J., 2017. Design and Evaluation of a Short Version of the User Experience Questionnaire (UEQ-S). International Journal of Interactive Multimedia and Artificial Intelligence, 4(6), p.103.

STATCOUNTER, 2018. Operating System Market Share Worldwide. [online] Available at: $<$ https://gs.statcounter.com/os-marketshare\#monthly-201801-201812-bar> [Accessed 14 Nov. 2019].

SUASTINI, N.K., LANANG, I.G., RADITYA, A. and Satwika, I.P., 2018. Analisis Pengalaman Pengguna Pada Website Distro Management System ( Dimans ). Jurnal Ilmiah Teknik Informatika dan Sistem Informasi, [online] 7(3), pp.135-144. Available at: $\quad<$ http://ojs.stmikbanjarbaru.ac.id/index.php/jutisi/article/vie w/300/284>.

SULARSA, A. AND PRIHATMANTO, A.S., 2015. Evaluasi User Experiences Produk iDigital Museum dengan Menggunakan UEQ. Jurnal Teknologi Informasi, 2(2), pp.56-62.

SUSILO, E., WIJAYA, F.D. AND HARTANTO, R., 2018. Perancangan dan Evaluasi User Interface Aplikasi Smart Grid Berbasis Mobile Application. Jurnal Nasional Teknik Elektro dan Teknologi Informasi (JNTETI), 7(2), pp.150-157. 
Halaman ini sengaja dikosongkan 